\title{
Todo Marqueteiro é Mentiroso! A Verdade como um Diferencial de Vendas. O Perigo dos exageros na COMUNICAÇÃo.
}

Seth Godin. Tradução de Ricardo Bastos Vieira. Rio de Janeiro: Editora Elsevier, 2005. 202 p. ISBN 85-352-1850-5. Edição original: ISBN 1-59184-100-3.

Por Daniela Yoko Matsuzaki (UnB).

O marketing é a arte de convencer indivíduos de que o produto, pessoa e outrem, cuja exibição é feita nos mais diversos meios de comunicação, é a melhor opção para se ter como produto, serviço ou até como seu representante no governo. Muito se fala sobre como o marketing deve ser utilizado, quando ele passa a ser preconceituoso, se ele deve ou não mentir. Em face dessas discussões, o autor Seth Godin escreveu essa obra que busca elucidar, por meio de exemplos, como as empresas e os homens obtêm o sucesso ou o fracasso na utilização do marketing.

O escritor Seth Godin é graduado em filosofia e ciência da computação na Universidade Tufts e obteve o mestrado em marketing na Stanford Business School. Foi vice-presidente de marketing Direto da Yahoo!, o criador da Yoyodyne, e ajudou a moldar a companhia com base no pioneiro Marketing de Permissão on-line que, como o próprio nome indica, este tipo de estratégia de Marketing é a permissão dos usuários que visitam o site para lhes enviar informações sobre produtos e serviços da empresa. A melhor maneira de conseguir esta permissão é pedir ao internauta que se inscreva como utilizador do site, pois, assim, estará a abrir um canal direto entre ele próprio e a organização.

A obra é dividida em nove segmentos, que se subdividem em três partes: $1^{\circ}$ parte - Destaques e Tem Marketing?. $2^{\circ}$ parte - Etapa 1: A visão de mundo das pessoas e o enquadramento já estavam lá antes de você chegar; Etapa 2: As pessoas percebem apenas aquilo que é novo; então, escolhem por adivinhação; Etapa 3: As primeiras impressões dão início à história; Etapa 4: Grandes marqueteiros contam histórias em que acreditamos; e Etapa 5: Empresas que nutrem um desejo incontrolável pela autenticidade. $3^{\circ}$ parte - Apêndice-bônus 1: Os mestres na arte de contar histórias e os que ainda estão aprendendo; e o Apêndice-bônus 2: Movimentos avançados. 
Seth Godin conceitua o verdadeiro marketing e que, para obter sucesso nessa área, os marqueteiros devem contar histórias para os consumidores, histórias que acrescentem algo à sua visão de mundo, podendo ser histórias falsas, mas que devem ser autênticas. Quando se pretende contar uma história, ela deve primeiramente convencer seu mentor para, depois, convencer os demais. Se quem conta não acredita fielmente na história, dificilmente convencerá alguém. Segundo Godin, contar histórias é a única forma conhecida de se disseminar uma idéia. Além disso, todos nós somos mentirosos e estamos diariamente contando mentiras para nós mesmos, porque isso facilita nossas vidas no mundo complicado em que vivemos.

O marketing não deve objetivar o agrado de todos os consumidores, porque essa é uma situação impossível de se consolidar; também não deve tentar mudar a visão de mundo dos consumidores, porque não gostamos de admitir que estamos errados. Logo, o marketing precisa estar voltado para um grupo de pessoas que têm a mesma visão de mundo e essas pessoas irão convencer as demais que elas estão corretas. A razão pela qual a maioria das organizações está em dificuldades, com margens de lucros reduzidas, é que se vêem como vendedoras de commodities, sendo que os clientes geralmente obtêm o que são convencidos a comprar e não o de que realmente necessitam.

O livro apresenta diversas virtudes que vão desde a sua estrutura física até o seu conteúdo. No aspecto físico, a capa é bastante atrativa e instigante. Característica peculiar do autor observada também em seus outros livros, como: A Vaca Roxa (Godin, 2002), que trata do marketing de forma difusa.

Em seu teor, o autor a todo o momento conversa com o leitor como se já o conhecesse há tempos e enriqueceu seu livro com inúmeros exemplos da prática de marketing. Uma das falhas do livro é que, apesar dos variados exemplos, alguns deles não são bem compreendidos, pois mencionam fatos que fazem parte do cotidiano norte-americano, ou empresas que não existem no Brasil. Outra falha no livro é a sua divisão que tem títulos confusos, não demonstrando uma seqüência lógica de assuntos.

Contudo, a obra é de grande excelência, devido à amplitude concedida ao marketing; mostra que o melhor é aquele que nos conquista por intermédio dos sentidos de modo sutil. Esta forma contraria o marketing impositivo que diversas instituições insistem em praticar e que em pouco tempo leva a organização a ter prejuízos. E, ao contrário do que inúmeras empresas pensam, o fato de terem recursos, sucesso e consumidores não significa que será sempre assim e não devem mais investir em marketing; ele deve ser reformulado constantemente 
para manter essas virtudes. Recomendo a obra para todos, os empresários, os apreciadores dessa área e os acadêmicos de Administração, pois ajudará a tirar dúvidas a respeito desse assunto.

\section{Referencia Bibliográfica}

Godin, S. (2002).

A Vaca Roxa. Rio de Janeiro: Elsevier. 
